\title{
Neuroclusal rehabilitation and planas direct tracks in the posterior crossbite treatment
}

\author{
Reabilitação neuroclusal e pistas diretas de planas na correção da mordida cruzada posterior
}

\author{
Artênio José Isper GARBIN \\ Bruno WAKAYAMA ${ }^{1}$ \\ Tânia Adas Saliba ROVIDA ${ }^{1}$ \\ Cléa Adas Saliba GARBIN'1
}

\section{ABSTRACT}

\section{Objective}

To evaluate the effectiveness of neuroclusal rehabilitation treatment using Planas Direct for posterior crossbite correction.

\section{Methods}

This is a clinical study in which 43 children were selected, of both sexes, between 3 and 6 years old, diagnosed with posterior crossbite and midline deviation. Interviews were conducted with the parents in order to ascertain the practice of harmful habits. The treatment was based on neuroclusal rehabilitation in order to investigate and eliminate the occlusal obstacles which depreciate the stomatognathic system. The aim of the study was also to reprogram the affected neuromuscular activity. Planas direct were performed on crossed teeth in order to restructure the neuroclusal area and the stomatognathic system, as well. Epi Info software, 3.5.4 for Windows, through the distribution of frequencies and the Pearson chi-square test were used for statistical analysis.

\section{Results}

Occlusal restoration in $79 \%$ of children was performed however $21 \%$ abandoned treatment. The crossbite and midline correction period ranged from from $14^{\circ}$ to the $91^{\circ}$ treatment. Significant associations of the variables were observed as follows: deleterious habits ( $p=0.0001$ ) and midline deviation $(p=0.0001)$ at the beginning or end of treatment.

\section{Conclusion}

It was concluded that the neuroclusal rehabilitation and Direct Slopes Planas were effective in correcting the posterior crossbite.

Indexing term: Malocclusion. Occlusal adjustment. Orthodontics.

\section{RESUMO}

Objetivo

Avaliar a eficácia do tratamento da reabilitação neuroclusal com as Pistas Diretas Planas na correção das mordidas cruzadas posteriores.

\section{Métodos}

Trata-se de um estudo clínico no qual foram selecionadas 43 crianças, de ambos os sexos, entre 3 e 6 anos de idade, diagnosticadas com mordida cruzada posterior funcional e desvio de linha média. Foram realizadas entrevistas com os responsáveis dos participantes, para averiguar a prática de hábitos deletérios. O tratamento baseou-se na reabilitação neuroclusal, no intuito de investigar e eliminar os empecilhos oclusais que depreciam o sistema estomatognático, e assim, reprogramar a atividade neuromuscular afetada. Foram confeccionadas as Pistas Diretas de Planas nos dentes cruzados, a fim de reestrutura os estímulos neuroclusais e o sistema estomatognático. Na análise estatística, utilizou-se o software Epi Info software, versão 3.5.4 for Windows, por meio da distribuição das frequências e o Teste do Qui-quadrado de Pearson.

\section{Resultados}

Houve o restabelecimento oclusal em $79 \%$ das crianças, visto que $21 \%$ abandonaram o tratamento. O período de correção da mordida cruzada e linha média compreenderam-se ao $14^{\circ}$ ao $91^{\circ}$ de tratamento. Foram observadas associações significativas das variáveis: hábitos deletérios $(p=0.0001)$ e desvio de linha média $(p=0.0001)$ no início e final do tratamento.

\section{Conclusão}

Conclui-se que a reabilitação neuroclusal e as Pistas Direta de Planas foram eficazes na correção das mordidas cruzadas posteriores.

Termos de indexação: Má oclusão. Ajuste oclusal. Ortodontia.

\footnotetext{
${ }^{1}$ Universidade Estadual Paulista Júlio de Mesquita Filho, Faculdade de Odontologia, Departamento de Odontopediatria e Odontologia Social. Rua José Bonifácio, 1193, 16015-050 - Araçatuba, SP, Brasil. Correspondência para / Correspondence to: B WAKAYAMA. E-mail: <brunowakayama@gmail. com>.
} 


\section{INTRODUCTION}

Although crossbite is not considered a disease, its diagnosis and early treatment are fundamental, once this occlusal disharmony is not self-corrective and it results in skeletal alterations in the adult age ${ }^{1}$. Intervention in this malocclusion in the childhood, the period of great biologic development potential and bone remodeling, will favor facial growth without sequelae, and the desired prognosis is guaranteed ${ }^{2-3}$.

Diagnosis of posterior crossbite is determined as disproportionate transverse relationships between the maxillomandibular structures, in maximum intercuspation and centric relation. This manifestation maybe unilateral or bilateral and it is didactically classified as skeletal, dental or functional| ${ }^{4-5}$. Functional posterior crossbite is the most prevalent one, being characterized as a mandibular postural deviation due to premature contact between teeth ${ }^{6}$.

The child presenting crossbite shows an asymmetrical condyle-fossa relationship, moving the mandible to the most comfortable side due to the influence of occlusal barriers ${ }^{6-7}$. The main etiology factors which collaborate to the appearance of functional posterior crossbite are as follows: omission of breastfeeding and deleterious habits, such as digital sucking, the use of pacifiers and bottles ${ }^{8-10}$.

Regarding the prevalence of posterior crossbite high rates in the early childhood ${ }^{11-12}$ together with the depreciation of the stomatognathic system structures in face of occlusal-functional alterations ${ }^{13-14}$, the early interception of this malocclusion is mandatory so as to diminish its sequelae. Therefore, by treating the mandibular deviation when craniofacial sutures are still fusioning, normal growth and morphological development will be favored $^{15}$

Stated thus, it is prudent to elect a type of treatment which is effective in the restitution of the occlusal harmony, in the reestablishment of the stomatognathic equilibrium, and which does not require the patient's direct cooperation. In this way, the treatment with Neuroclusal Rehabilitation (NOR) is advisable in the case of posterior crossbite, due to its properties and easy technical execution.

Neuroclusal Rehabilitation is, as it is defined, the study of the etiologies which influence the functional structures, resulting in morphological alterations in the stomatognathic system ${ }^{16-17}$. Consequently, the purpose of NOR is the early diagnosis of the latent stimuli over the stomatognathic development, may that be due to the lack, excess or inappropriate neuromuscular excitement ${ }^{18}$.
Concerning the functional posterior crossbite, NOR acts in the reprogramming of the neuromuscular activity with the removal of premature contacts, moving it to a correct posture of craniofacial development ${ }^{18}$.

Occlusal adjustments should be performed in centric position in order to level the median line and highlight the areas of premature contacts. In this situation, the interocclusal distance can be observed in lateral movement, being it called by Planas as Planas' Functional Masticatory Angle (PFMA) ${ }^{17}$. This was determined once the interocclusal distance is the preferred side of mastication, due to the principle of the minimum vertical dimension, that is, the individual always masticates on the side in which the PFMA is smaller ${ }^{19}$. Therefore, the balancing side, opposite the mastication one, is more stimulated than the functional side due to the glide and condyle excitement which occur in the non-cross side.

In the cases in which the occlusal adjustments were not sufficient, the use of Planas Direct Tracks should provide help for an adequate neural excitement, reflecting in the posture of the bone bases, in the muscle tone, in the facial remodeling and in the occlusal harmonization ${ }^{18,20}$. For the confection of the Direct Tracks, it is observed the established protocol for adhesive restorations, with the insertion of the photopolymerizable composite resin in the upper teeth of the cross side in the shape of inclined planes ${ }^{18}$. In this way the mandible will not find the minimum vertical dimension favoring the correct neuromuscular excitement. Thus, the aim of this study was to evaluate whether the treatment of selective grinding and the use of Planas Direct Tracks were efficient in the correction of posterior crossbite.

\section{METHODS}

This survey was submitted to Plataforma Brasil and the consent form was signed by the parents/guardians. It consists of a clinical study in which children from two nursery schools of a medium-size city in the northwest of the state of São Paulo participated.

120 children between 3 and 6 years of age were examined, from which $43(35,33 \%)$ were selected to compose the sample, following the inclusion criteria: 1) Present the diagnosis of functional posterior crossbite; 2) Do not present other associated malocclusion; 3) Have not undergone orthodontic treatment; 4) parents/guardians signed the consent form .

Interviews with the children's parents/guardians were conducted to verify the participants' behavioral profiles concerning the odontological treatment and 
question the practice of deleterious habits.

For the Neuroclusal Rehabilitation treatment protocol, the mandible was guided to the centric position to level the median line, determine the existing disharmonic contacts and highlight the interocclusal rest space (PFMA) in the region of the deciduous molars.

In the clinical care, for the registration of the premature contacts, carbon paper was used to refine such occlusal interferences to be removed. In this way, based on the premise of NOR, to incite deprogramming of the occlusion and stimulate the correct neuromuscular excitement, diamond burs were used, preferably with a wheel form for the performing of the selective grinding procedure.

After the removal of the premature contacts, Planas Direct Tracks were made in inclined planes and installed in the upper teeth of the cross side, so that the mandible would find the minimum vertical dimension on the opposite side and unconsciously stimulate the balancing side. For the construction of the tracks, the following protocol was followed (Figure 1): previous prophylaxis of the dental arcades, relative isolation of the surgical field, conditioning with phosphoric acid at 37\%, application of the adhesive system and insertion of the photopolymerizable composite resin in inclined planes configurating the dental anatomy.

Afterwards the occlusal adjustments, finishing and polishing procedures were performed. Follow-up care happened every fifteen days for evaluation and performing of adjustments when necessary.

For the statistical analysis of the quantitative data collected in the interviews with the children's parents/ guardians Epi Info software, version 3.5.4 for Windows, through frequency distribution, and Pearson's ChisquareTest were used.
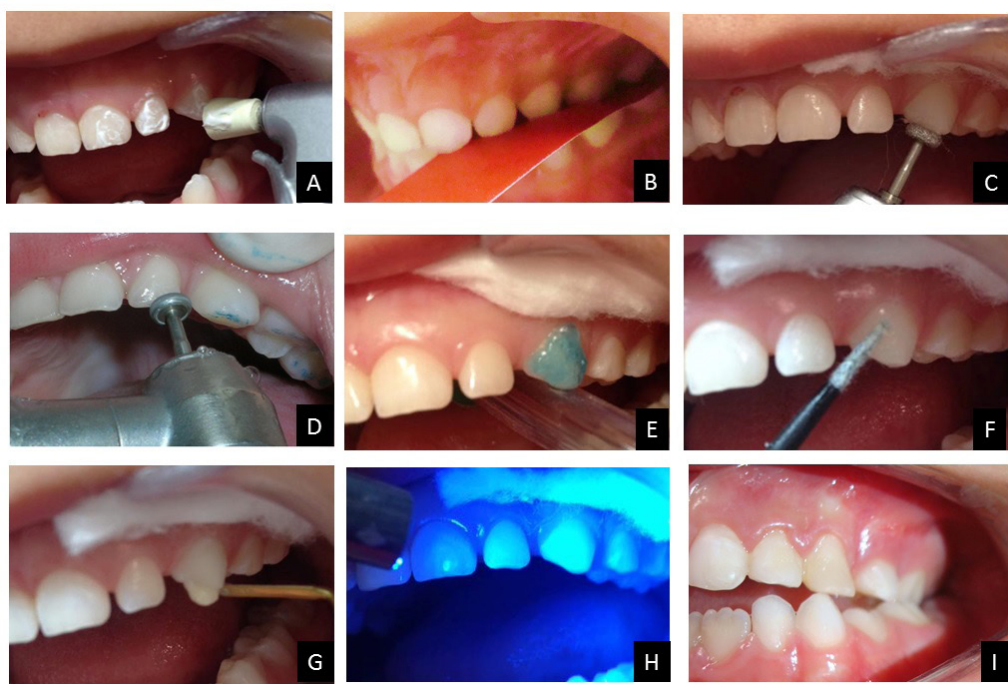

Figure 1. A - prophylaxis; B - carbon paper; C - occlusal adjustment; D - occlusal adjustment; E - conditioning surface; F - insertion of the adhesive agent; G - construction of the track with composite resin; $\mathrm{H}$ - photopolymerization; I - planas direct track.

\section{RESULTS}

Table 1. General profile of the sample.

\begin{tabular}{lll}
\hline & $\mathbf{n}$ & $\boldsymbol{f}$ \\
\hline Male & 19 & 44 \\
Female & 24 & 56 \\
Age & Average of 4,35 years & \\
Right PC & 22 & 51,2 \\
Left PC & 17 & 39,5 \\
Bilateral PC & 4 & 9,3 \\
With habit & 36 & 83,7 \\
Without habit & 7 & 16,3 \\
With median line deviation & 43 & 100 \\
Without median line deviation & 0 & 0 \\
\hline
\end{tabular}

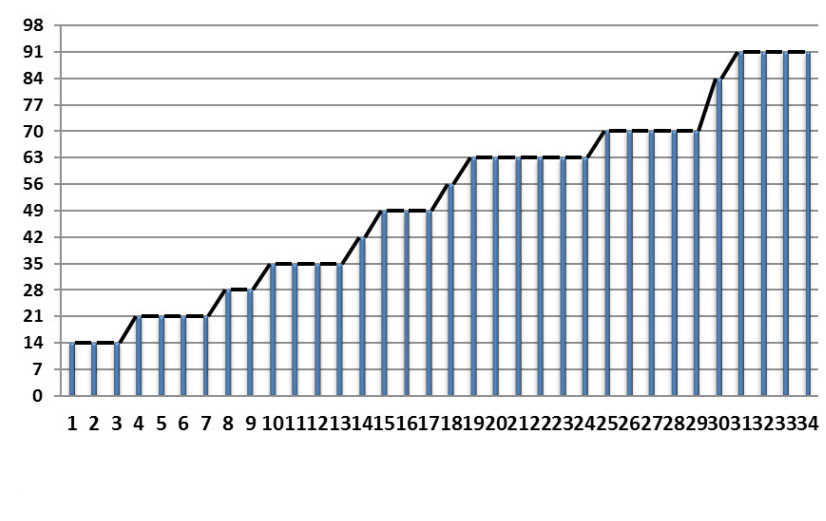

Figure 2. Patients' distribution as to the day of correcting the functional posterior crossbite. Araçatuba-SP, 2014 
Table 2. Analysis of the age group, as to the day of the posterior crossbite correction. Araçatuba (SP), 2014

\begin{tabular}{lllllllllllll}
\hline Age & \multicolumn{11}{c}{ Treatment Timeline } \\
Group & 14 & 21 & 28 & 35 & 42 & 49 & 56 & 63 & 70 & 77 & 84 & 91 \\
\hline $3 \mid---4$ & & & & & 1 & & 1 & 5 & 2 & & & 2 \\
$4 \mid---5$ & 1 & 2 & 1 & 2 & & 2 & & 1 & 2 & & 1 & 2 \\
$5 \mid---6$ & 1 & 1 & 1 & 2 & & 1 & & & 1 & & & \\
$6 \mid$ & 1 & 1 & & & & & & & & & & \\
\hline
\end{tabular}
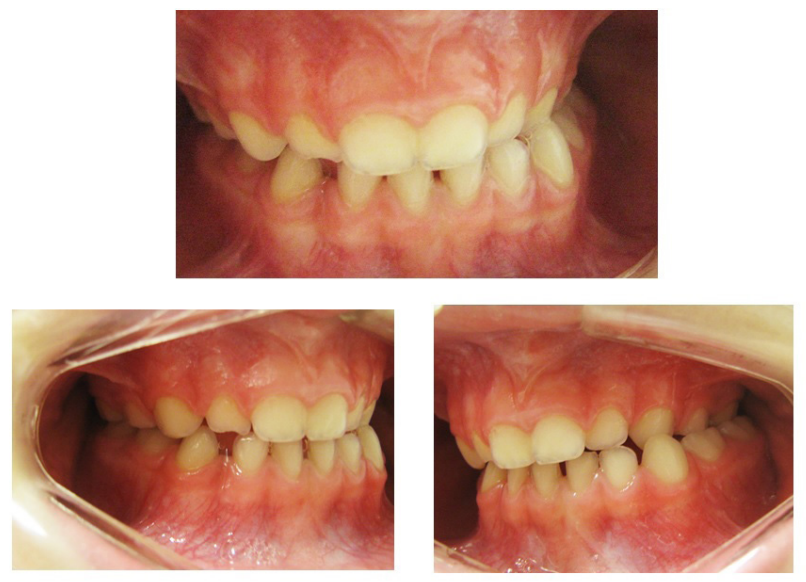

Figure 3. Crossbite, before the treatment
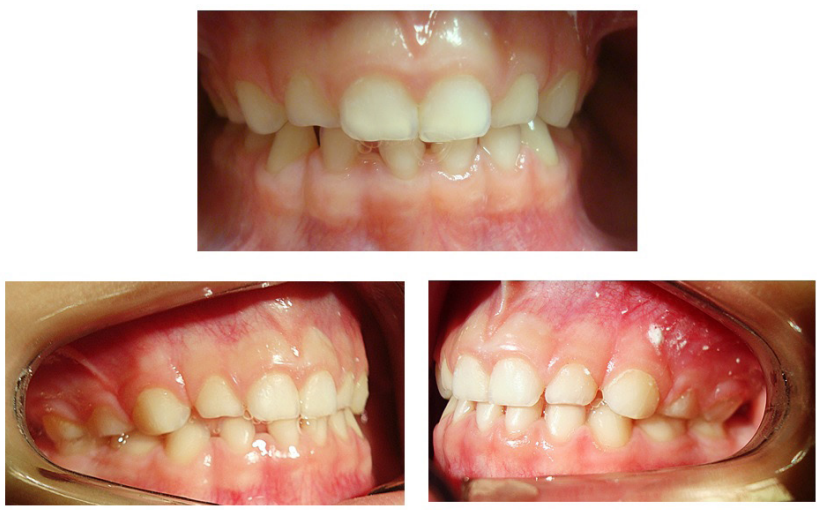

Figure 4. Crossbite corrected after 56 days of treatment.

From the total of the sample, the functional posterior crossbite was successfully corrected in $34(79 \%)$ of the children, whereas $9(21 \%)$ of the participants still remained with the malocclusion, due to their noncooperation to the clinical procedures, by either missing the appointments or neglecting the treatment.

In relation to the figure 2 , the occlusal reestablishment can be observed in the period of 14 to
91 days of treatment. In table 2, a higher proportion of correction of the crossbite is observed on the $63^{\text {rd }}$ and $70^{\text {th }}$ day of treatment, among 3 and 5-year-old patients.

Table 3. Analysis of uncrossed patients, as to their habits and median line deviation in the beginning and end of treatment. Araçatuba (SP), 2014

\begin{tabular}{|c|c|c|c|c|c|}
\hline \multirow{2}{*}{ Variables } & \multicolumn{2}{|c|}{$\begin{array}{l}\text { Beginning of } \\
\text { treatment }\end{array}$} & \multicolumn{3}{|c|}{ End of treatment } \\
\hline & $n$ & $f$ & $n$ & $f$ & $P$ value \\
\hline With habit & 27 & 79,4 & 2 & 5,9 & 0.0001 \\
\hline Without habit & 7 & 20,6 & 32 & 94,1 & \\
\hline $\begin{array}{l}\text { With median line } \\
\text { deviation }\end{array}$ & 34 & 100 & 0 & 0 & 0.0001 \\
\hline $\begin{array}{l}\text { Without median line } \\
\text { deviation }\end{array}$ & 0 & 0 & 34 & 100 & \\
\hline
\end{tabular}

Analyzing the table 3 it can be observed that initially $79.4 \%$ of the participants made use of some sucking habit, of which $94.1 \%$ ceased the deleterious habits by the end of the treatment. Analyzing the median line deviation, $100 \%$ of the patients obtained the desired prognosis.

\section{DISCUSSION}

Considering the given results: it was observed in, figure 2 the crossbite correction between the $14^{\text {th }}$ and $91^{\text {st }}$ day of treatment; in table $I$, the higher rate of treatment success was shown on the $63^{\text {rd }}$ and $70^{\text {th }}$ day, for the younger age individuals. These data demonstrate the efficiency of the Neuroclusal Rehabilitation in the intervention of posterior crossbite, given the little amount of time of treatment and the effectiveness in the early interception of the malocclusion.

The results were satisfactory once the intervention of the posterior crossbite occurred in the individuals' growth period and fusioning of the craniofacial sutures. In this way, the treatment's prognosis becomes favorable and collaborates to the minimization of the sequelae originating from the malocclusion ${ }^{2,21}$. However, the patients' early age, associated with their first visit to the dentist's office, makes it necessary to previously accustom them to the new environment. Therefore, it is fundamental to create trusting bonds between professional and patient in order to reduce their anxiety and fear of the odontological treatment ${ }^{22}$. 
Table III showed statistically meaningful associations related to the deleterious habits $(p=0.0001)$ and median line deviation $(p=0.001)$ at the beginning and in the end of the treatment. Due to this, it can be inferred the action of the treatment upon the ceasing of the deleterious habits which acted depreciating the individual's orofacial structure, as well as in correcting the median line that was previously dislocated.

In the diagnosis of unilateral posterior crossbite, it is fundamental to detect the alterations of the facial structures from the cross side, once this disharmony in the individual's development phase reflects later in a permanent skeletal asymmetry pattern ${ }^{23}$. Therefore, in order to hold the sequelae originating from facial asymmetry, it is prudent to early intervene in the crossbite so to reestablish the muscular pattern, and, thus, restructure the facial symmetry and the distribution of the masticatory force ${ }^{24}$.

Some authors ${ }^{9,25-26}$, observed in their studies the significant association between the use of pacifiers and bottles, early weaning and malocclusions in children with deciduous and mixed dentition. The sucking habit provokes an orofacial muscular disturb, reflecting on the craniofacial structures, favoring the appearance of malocclusions such as anterior open bite and crossbite. In this way, it is necessary the professionals' and parents' action towards motivating these individuals to cease this behavior. Based on this premise, it is of crucial importance that these habits are ceased during the treatment, for the non-nutritive sucking interrupts the action of the treatment due to inappropriate neuromuscular stimuli ${ }^{18}$.

Regarding the results, the treatment of the NOR, with Planas Direct Tracks technique, proved satisfactory

\section{REFERENCES}

1. Hebling SRF, Pereira AC, Hebling E, Meneghim MC. Considerações para elaboração de protocolo de assistência ortodôntica em saúde coletiva. Cien Saude Colet. 2007;2(4):1067-1078. doi: $10.1590 / S 1413-81232007000400028$

2. Melink S, Vagner MV, Hocevar-Boltezar I, Ovsenik M. Posterior crossbite in the deciduous dentition period, its relation with sucking habits, irregular orofacial functions, and otolaryngological findings. Am J Orthod Dentofacial Orthop. 2010 Jul;138(1):32-40. doi: 10.1016/j.ajodo.2008.09.029

3. Irujo LC. Tratamiento temprano de las maloclusiones sin aparatología funcional: presentación de dos casos clínicos. Int J Odontostomat. 2014 Sep;8(2):253-60.

4. Malandris M, Mahoney EK. Aetiology, diagnosis and treatment of posterior cross-bites in the primary dentition. Int J Paediatr Dent. 2004;14(3):155-66. doi: 10.1111/j.1365-263X.2004.00546.x in the correction of posterior crossbite (figure 3 and 4). This prognosis originates from the restructuring of the neuromuscular stimuli, favoring the good physiological development of the previously affected structures ${ }^{3,16,18,20,27-30}$.

The NOR treatment effectiveness with Planas Direct Tracks is reiterated due to its characteristic of redefining the postural morphology of the stomatognathic system, and for presenting intrinsic advantages to the treatment such as: the patient's passive cooperation to the action of the tracks, the use of basic consumption materials as well as their confection by general practitioners in a single clinical session ${ }^{18,29-30}$.

\section{CONCLUSION}

It can be concluded that the early intervention of the posterior crossbite with the treatment of Neuroclusal Rehabilitation using Planas Direct Tracks was effective, promoting occlusal equilibrium and harmony, as well as the median line correction.

\section{Collaborators}

AJI GARBIN was in charge of manuscript and research design as well as manuscript content critical review. B WAKAYAMA was responsible for the study outline, data interpretation and writing the article. TAS ROVIDA was in charge of study outline, data interpretation and writting the article. IAS GARBIN was responsible for data analysis and interpretation as well as critical review of content.

5. Silva Filho OG, Silva PRB, Rego MVNN. Capezolla Filho L. Epidemiologia da mordida cruzada posterior na dentadura decídua. J Bras Odontopediatr Odontol Bebê. 2003:6(29):61-8.

6. Locks A, Weissheimer A, Ritter DE, Ribeiro GLU, Menezes LM, Derech CD, et al. Mordida cruzada posterior: uma classificação mais didática. Rev Dental Press Ortodon Ortop Facial. 2008;13(2):146-58

7. Lippold C, Stamm T, Meyer U, Végh A, Moiseenko T, Danesh G. Early treatment of posterior crossbite - a randomised clinical trial. Trials. 2013 Jan;14:20. doi: 10.1186/1745-6215-14-20

8. Carvalho FS, Carvalho CAP, Peres-Sales A, Bastos JRM, SalesPeres HC. Epidemiology of malocclusion in children and adolescents: a critic review. RGO, Rev Gaúch Odontol. 2014 Set;62(3):253-60.

9. Agarwal SS, Nehra K, Sharma M, Jayan B, Poonia A, Bhattal $\mathrm{H}$. Association between breastfeeding duration, non-nutritive sucking habits and dental arch dimensions in deciduous 
dentition: a cross-sectional study. Prog Orthod. 2014 Oct 31;15(1):59. doi: 10.1186/s40510-014-0059-4

10. Thilander B, Lennartsson B. A study of children with unilateral posterior crossbite, treated and untreated, in the deciduous dentition--occlusal and skeletal characteristics of significance in predicting the long-term outcome. J Orofac Orthop. 2002 Sep;63(5):371-83.

11. Normando TS, Barroso RF, Normando D. Influence of the socioeconomic status on the prevalence of malocclusion in the primary dentition. Dental Press J Orthod. 2015 JanFeb;20(1):74-8. doi: 10.1590/2176-9451.20.1.074-078.oar

12. Martins JCR, Sinimbu CMB, Dinelli TCS, Martins LPM. Prevalência de má- oclusão em pré-escolares de Araraquara: relação da dentição decídua com hábitos e nível sócio econômico. Rev Dental Press Ortod Ortop Facial. 1998;3(6):35-43.

13. Chiodelli L, Pacheco AB, Missau TS, Silva AMT, Corrêa ECR. Association among stomatognathic functions, dental occlusion and temporomandibular disorder signs in asymptomatic women. Rev CEFAC. 2015 Jan-Fev; 17(1):117-24.

14. Takeshita $N$, Ishida $M$, Watanabe $H$, Hashimoto $T$, Daimaruya $T$, Hasegawa M, et al. Improvement of asymmetric stomatognathic functions, unilateral crossbite, and facial esthetics in a patient with skeletal Class III malocclusion and mandibular asymmetry, treated with orthognathic surgery. Am J Orthod Dentofacial Orthop. 2013 Sep;144(3):441-54. doi: 10.1016/j. ajodo.2012.09.024

15. Garbin AJl, Guedes-Pinto E, Grieco FAD. Bioprogressiva e reabilitação neuro-oclusal: a evolução da Ortodontia. In: Garbin AJl, Garbin RAl, Aranha MF. Problemas transversais. Araçatuba: Editora Somos; 2009. p. 163-200.

16. Santos RR, Garbin AJl, Garbin CAS. Early correction of malocclusion using planas direct tracks. Case reports Dent. 2013;2013:1-4. doi: 10.1155/2013/395784

17. Planas P. Reabilitação neuroclusal. $2^{a}$ ed. Rio de Janeiro: Medsi; 1997.

18. Garbin AJl, Wakayama B, Santos RR, Rovida TAS, Garbin CAS. Pistas diretas planas para o tratamento de mordida cruzada posterior. Rev Cubana Estomatol. 2014;51(1):113-20.

19. Pignataro Neto G, Bérzinll F, Rontani RMP. Identificação do lado de preferência mastigatória através de exame eletromiográfico comparado ao visual. Rev Dent Press Ortodon Ortop Facial. 2004;9(4):77-85.

20. Chibinski ACR, Czlusniak GD. Evaluation of treatment for functional posterior crossbite ofthe deciduous dentition using Planas' direct tracks. Indian J Dent Res. 2011; 22(5):654-58. doi: 10.4103/0970-9290.93451
21. Kilic N, Kiki A, Oktay H. Condylar asymmetry in unilateral posterior crossbite patients. Am J Orthod Dentofacial Orthop. 2008;133(3):382-7. doi: 10.1016/j.ajodo.2006.04.041

22. Gomes SSR, Bezerra ACB, Castro AM, Tavares M, Teixeira RR, Spindola FS, et al. Comportamento em crianças pré-escolares na primeira consulta odontológica: relação entre medidas objetivas e medidas subjetivas. J Manag Prim Health Care. 2013;4(2):1029.

23. Schiavinato J, Vedovello SAS, Valdrigui $H$, Vedovello Filho $\mathrm{M}$, Lucato AS. Assimentria facial em indivíduos com mordida cruzada posterior por meio de fotografias. RGO, Rev Gaúch Odontol. 2010;18(1):81-3.

24. Primozic J, Richmond S, Kau CH, Zhurov A, Ovsenik M. Three-dimensional evaluation of early crossbite correction: a longitudinal study. Eur J Orthod. 2013;35(1):7-13. doi: 10.1093/ ejo/cjq198

25. Moimaz SAS, Rocha NB, Garbin AJl, Saliba O. A influência da prática do aleitamento materno na aquisição de hábitos de sucção não nutritivos e prevenção de oclusopatias. Rev Odontol UNESP. 2013;42(1):31-6.

26. Freire GLM, Ferrari JCL, Percinoto C. Association between maternal breastfeeding and the development of non-nutritive sucking habits. RGO, Rev. Gaúch Odontol. 2015;63(2):139-144. doi: 10.1590/1981-863720150002000012295

27. Carbone IL. Tratamiento temprano de las maloclusiones sin aparatologia funcional: presentacion de dos casos clinicos. Int J Odontostomat. 2014;8(2):253-60.

28. Gribel MN. Planas direct tracks in the early treatment of unilateral crossbite with mandibular postural deviation: why worry so soon? World J Orthod. 2002;3:239-49.

29. Ramirez-Yañez GO. Planas direct tracks for early crossbite correction. J Clin Orthod. 2003;37(6):294-8.

30. Chibinski ACR; Czlusniak GD; Melo MD. Pistas diretas planas: terapia ortopédica para correção de mordida cruzada funcional. Rev Clin Ortodon Dental Press. 2005;4(3):64-72.

Received on: 17/2/2016 Final version resubmitted on: 12/8/2016 Approved on: $17 / 1 / 2017$ 